\title{
An Application of Analytic Hierarchy Process (AHP) for Measuring Sustainable Development in an Organization Implementing a Community Development Program
}

\author{
Grace Sumbung ${ }^{1}$, Agus Suman ${ }^{2}$, Kliwon Hidayat ${ }^{3}$, Paulus Kindangen ${ }^{4}$ \\ ${ }^{1}$ Postgraduate Student of Environmental and Development Study, Brawijaya University, Malang, 65145 East \\ Java, Indonesia and Budi Utomo High School of Economics, Manado, North Sulawesi, Indonesia. \\ ${ }^{2}$ Faculty of Economics and Business, Brawijaya University, Malang, 65145 East Java, Indonesia. \\ ${ }^{3}$ Faculty of Agriculture, Brawijaya University, Malang, 65145 East Java, Indonesia \\ ${ }^{4}$ Faculty of Economics and Business, Sam Ratulangi University, Manado, North Sulawesi, Indonesia
}

\begin{abstract}
Christian Gospel Church Minahasa (GMIM) is a church organization that is quite concerned with community development carried out by its sub-organization namely BLPT. By using sustainable development framework and applying the analytic hierarchy process (AHP), this study aims at finding important factors (critera) contributing to sustainable development components in BLPT, this study shows that "Utilization of waste for handicraft (ENV22)" has the first rank, "Planting coconut trees on vacant land (ENV12)" locates in the second rank, and "The relationship between land owners with coconut tree growers (SOC22)" in the third rank. It could be said that BLPT has more environmetal and social characters than economic one.
\end{abstract}

Key words: Analytic Hierarchy Process (AHP), community development, sustainable development, BLPT

\section{Introduction}

There is growing awareness of sustainable development. This is happening for a number of reasons. The massive development and resources depletion has been reported to be one of the reasons. Moreover, the social consequences of the natural resources exploitation and unbalance development has been discussed in detail elsewhere. Mainly, it encompasses increasing number of natural resources depletion and poverty [1]. Social studies of poverty indicate that there are relationship among poverty and development. Poverty and lack of human education is the barrier for development. Directly or indirectly, poverty is the one of the most important factors in nation's development. According to scholar, people must be seen as part of the solution, rather than as part of the problems [2]. In such a case, developing and enhancing people capacity through its economic aspect, its social aspect (i.e. social organization), and environmental aspect are important. It is particularly important when central government facing resources limitation [3].

The paragraph above illustrates that sustainable development includes three criterion, namely the economic criteria, social criteria and environmental criteria. Three criterion must necessarily be translated by the organization in its activities. This article, by applying analytic hierarchy process (AHP), will break down the three criterion into its components in the context of religious organizations, namely BLPT which operates under the supervision of Christian Evangelical Church Minahasa (GMIM).

\section{Conceptual Framework}

Christian Gospel Church Minahasa (GMIM) is a church organization based in Tomohon, North Sulawesi, with a service area covering three districts: Minahasa, Manado and Bitung. As duty bearers in evangelism and education to the community, GMIM is quite concerned with social issues by establishing the Citizens Development Center Church (PPWG) where is located in the district of Tomohon. During its development, PPWG managed to collect some help from church organizations in North Sulawesi and Central America and from abroad to build dormitories, halls and infrastructure was completed in 1987. Since then, PPWG open Work and Training Center Skills (BKLK).

At first BKLK conduct exercises work program consultant/building, furniture, electronics and mechanics, but in the end make the program processing and utilization of coconut wood as a flagship program. BKLK more advanced and show changes better with all the equipment and supplies as well as the administrative machinery.

In 1992 BKLK was changed to BLPT and designated as a place of training and education, research and utilization of natural ingredients available and abundant around North Sulawesi. BLPT working on palm trees that are no longer productive to creatively utilized and processed into furniture and souvenirs. There are 3 excellent programs BLPT, namely: (1) the level of vocational education for junior high school graduates, and employment programs for young people who drop out of school, (2) the program processing and utilization of 
coconut wood, and (3) the program processing and utilization of palm wood.

The existence BLPT with creative programs is quite instrumental in empowering communities, especially communities in North Sulawesi. BLPT role in this empowerment can be assessed from the economic, social, and environmental aspects. Departing from these three aspects, the conceptual framework is presented in Table 1.

Table 1. Conceptual Framework

\begin{tabular}{|c|c|c|}
\hline Criteria & Sub-Criteria & Sub-Sub-Criteria \\
\hline \multirow[t]{2}{*}{ Economic $(\mathrm{E})$} & Income (ECO1) & $\begin{array}{l}\text { Revenue for the management and admin BLPT (ECO11) } \\
\text { Revenue for the owner of the tree (ECO12) } \\
\text { Revenue for suppliers of coconut wood (ECO13) } \\
\text { Revenue for permanent workers (ECO14) } \\
\text { Revenue for temporary workers (ECO15) } \\
\text { Revenue for the seller coconut wood processing waste (ECO16) }\end{array}$ \\
\hline & Job creation (ECO2) & $\begin{array}{l}\text { Job for loggers (one package with the supplier) (ECO21) } \\
\text { Job for transporting coconut wood (ECO22) } \\
\text { Job for processed coconut wood (furniture and souvenirs) (ECO23) }\end{array}$ \\
\hline \multirow[b]{2}{*}{ Social (S) } & Social role of BLPT (SOC1) & $\begin{array}{l}\text { Improving education for children (SOC11) } \\
\text { Increasing expertise and skills for school dropouts (SOC12) } \\
\text { Increasing sense of pride and useful for alumni in their community } \\
\text { (SOC13) }\end{array}$ \\
\hline & Contractual relation (SOC2) & $\begin{array}{l}\text { The relationship between the owner of a palm tree with a team of } \\
\text { contractors/suppliers (SOC21) } \\
\text { The relationship between land owners with coconut tree growers } \\
\text { (SOC22) } \\
\text { The relationship between coconut trees suppliers with BLPT } \\
\text { (SOC11) }\end{array}$ \\
\hline \multirow{2}{*}{ Environmental (ENV) } & $\begin{array}{l}\text { Rejuvenation of coconut tree } \\
\text { (ENV1) }\end{array}$ & $\begin{array}{l}\text { Cutting down non-productive coconut trees (ENV11) } \\
\text { Planting coconut trees on vacant land (ENV12) }\end{array}$ \\
\hline & $\begin{array}{l}\text { Recycling waste of coconut } \\
\text { trees (ENV2) }\end{array}$ & $\begin{array}{l}\text { Utilization of waste for fuel (ENV21) } \\
\text { Utilization of waste for handicraft (ENV22) }\end{array}$ \\
\hline
\end{tabular}

\subsection{Economic Criteria}

\subsubsection{Income}

Young people who drop out of school and work in BLPT besides getting an education and skills in processing and utilization of coconut wood as well get paid as workers. On the other hand, for those who do not work in the training centers can develop their own business out in accordance with the skills acquired during training.

Coconut wood raw material requirements are high by BLPT encourage people to fulfill a variety of ways. For owners of coconut land, they tend to sell coconut wood because it is more advantageous, whereas for the suppliers will purchase coconut trees to be cut down and the timber. In addition, suppliers can also rent the land for planting coconut trees. Communities can also buy coconut wood waste in BLPT to be resold or used alone for fuel. From these activities, community benefit economically and ultimately their incomes rise.

\subsubsection{Job Creation}

Children can go to the junior high school graduates and continuing education BLPT with special programs of education and training in the processing and utilization of coconut wood. They earn the equivalent of vocational education and so pass them recruited as an employee in the training hall. Of course, graduates BLPT a skilled labor in the productive age, and they are ready to work. While youth who have dropped out of school and nurtured in BLPT so out of education and training can work out or have my own business.

People who have coconut land in addition to taking advantage of the fruit also sell wood to the contractor for the production of raw materials BLPT. It becomes its own land for people who do not have coconut land. They bought a coconut tree from its owners and cut them down and sell it to BLPT. From one side, they are the suppliers of raw materials in the process of logging BLPT due to delivery to the site of production workers need loggers and freight services. Based on this, the supply of raw goods is involving coconut land owners, suppliers, workers loggers, and transport services. Thus, BLPT activities create jobs for people in the region.

Coconut wood are not fully absorbed by BLPT due to quality control coconut wood applied by the contractor. Most of the wood is used by local craftsmen to attempt raw materials that make furniture and souvenirs. The craftsmen are generally graduates coming out BLPT to choose to be self-employed. With its skills, they make furniture and building with coconut wood. In addition, they also utilize the remaining coconut wood or cannot be used as material for the manufacture of furniture souvenir. 
Landowners see sales opportunities quite favorably with some considerations such as the age of the tree that are not productive and occupy productive land and the risk of pest attack, then they sell coconut wood contractor to be used as raw material for furniture and souvenirs. For furniture craftsmen and souvenirs, results processing and utilization of waste oil timber can be a household fuel and could be sold. This is certainly a source of additional income for them.

Production BLPT besides being marketed abroad or to some areas in Indonesia also partly be a commodity for the surrounding community. BLPT products that are affordable to communities are put in the local market and this triggers the growth of furniture shops and souvenirs from coconut wood. Community opens business furniture and gift shop with goods or the supply of BLPT local craftsmen.

In addition to selling furniture and souvenirs, the community also opened a store that provides building materials from coconut wood. For building materials from coconut wood, they can take from BLPT and of craftsmen. The building materials from coconut wood are generally a package whose parts can be separated (knock down). While waste from producing that materials is also sold in stores or in marketplaces.

\subsection{Social Criteria \\ 1.2.1. Social Role of BLPT}

GMIM is fostering community not only in religious terms but also in terms of economic empowerment. The programs can also be perceived by society, especially the church. Teachings that life should always be corroborated helping each other within the congregation. Serving God in essence also serve fellow human beings. The spirit of the teachings like these that foster awareness to the community and the environment so as servants of God are obliged to assist and help to anyone in need.

Therefore consciousness as human togetherness, both deacon and the congregation has always worked shoulder to shoulder resolve social problems that occur in the community. Through PPWG, they realize those concerns by creating educational programs and training in BLPT. With the existence of this institution then the dialogue between the church and the community can be obtained through good cooperation in community development programs.

BLPT as a place of education and training for junior high school graduates and dropouts not only play a role in molding expertise and skills for learners, but also play a role in shaping the character of the community. Those who graduate and work in these places have pride both as alumni and community members. To parents, they are proud of being able to earn a living and could ease the burden on the family. For those who drop out of school and can receive education and training in BLPT will feel confident once out and make independent business. They are no longer unemployed who do not have the expertise and skills and only a burden on society.

\subsubsection{Contractual Relation}

Land owners sell wood coconut palm trees to the contractor/supplier because its limitations. Coconut tree felling took power loggers and timber shipments to BLPT also require transport and all it would cost. The existence of the contractor/supplier in this case is quite relieving the owner of both the financing and the selling price. With the bulk system, then the price can be ascertained and not subject to other fees. There is an agreement and mutual trust among the owner and the contractor/supplier as a long-standing relationship. It can also be shown by the lease of land by the contractor/supplier to the owner for replanting coconut trees. On the other hand, workers who work on the contractor loggers/suppliers also established a good relationship. Workers are working not only cut down palm trees but they also work to replant palm trees on land that has been cleared and the new land.

\subsection{Environmental Criteria}

Environmental understanding is something that is outside or around living creatures. Environmentalists give a definition that Environment (environment or habitat) is a complex system in which various factors influence reciprocal to each other and to the community of plants. According to the Encyclopedia of Forestry said that the Environment is the total number of non-genetic factors that influence the growth and reproduction of trees. It covers a very broad terms, such as soil, moisture, weather, pests and diseases influence, and sometimes human intervention.

\subsubsection{Rejuvenation of Coconut Trees}

Coconut trees can be aged up to over 100 years. Coconut trees on average productive of coconuts between the ages of 10 to 60 years. Does not rule out the possibility, palm trees can still bear fruit at the age of 60 years but the fruit is not as productive as the age below. If you look at the fruit, coconut tree is not as good as the old trees are still under the age of childbearing age. But for wood, old trees will be on good quality. Therefore these considerations, which are not productive trees will be cut down by the owner and the wood is sold as an ingredient of furniture and souvenirs. In addition, pests are also quite susceptible to trees that are 
older so they can make the timber is damaged or bad. Thus, the logging is also intended to replant causing rejuvenation in productive land.

Population palm trees are so many and the processing and utilization of wood by BLPT stimulate people to expand the planting of palm trees. Not just in the planting area or around the beach community, but the community also planted palm trees in vacant land or land that is not utilized by the owner. Even the contractor/supplier is willing to rent the vacant land to plant palm tree seedlings.

Contractor/supplier after logging is also willing to rent land owners of palm trees to be replanted palm trees with an agreement or specific agreement. New land use or land clearance is also good for rejuvenation of coconut trees. Old trees could be certainly unproductive and vulnerable to damage due to pest attacks. In addition, damage to the wood can also be a threat to young trees because of the same pests. Replanting in land clearance also bring good on the ground because the planting is done with cleaning the remnants of logging and processing of the back ground.

Tha demand for a big coconut wood makes people to sell coconut wood. With consideration of greater profits, people tend to take advantage of palm trees for sale as coconut wood. This fact encourages the public to sell as much as coconut wood and then replant palm trees. In fact, a certain amount of coconut tree cutting could lead to replant palm trees more than felled.

\subsubsection{Recycling Waste of Coconut Trees}

Waste processing and utilization of coconut wood is quite a lot and it took a long time to decompose in the soil. If thrown away, then this waste will pollute the environment habitat other than hard decomposed by soil. Not to mention, this waste can also carry less moderate odor when exposed to water and left long enough.

Utilization positively, coconut wood waste can be used as a household fuel and crafts. With this waste, the public can also make souvenirs that will be sold.

\section{Review of Literature}

The Analytic Hierarchy Process (AHP) is a mathematical method for analyzing complex decision problems under multiple criteria [4] [5] [6]. The management options for a particular decision problem are characterized by their attributes with respect to a set of detailed criteria [7]. An example of such a hierarchy is presented in Figure 1. At the top level, a goal is specified, in this case sustainable development in the BLPT. At the second level, all the objectives or criteria are listed, which in this example are environmental, economic and social objectives. At the bottom level, all the options are presented.

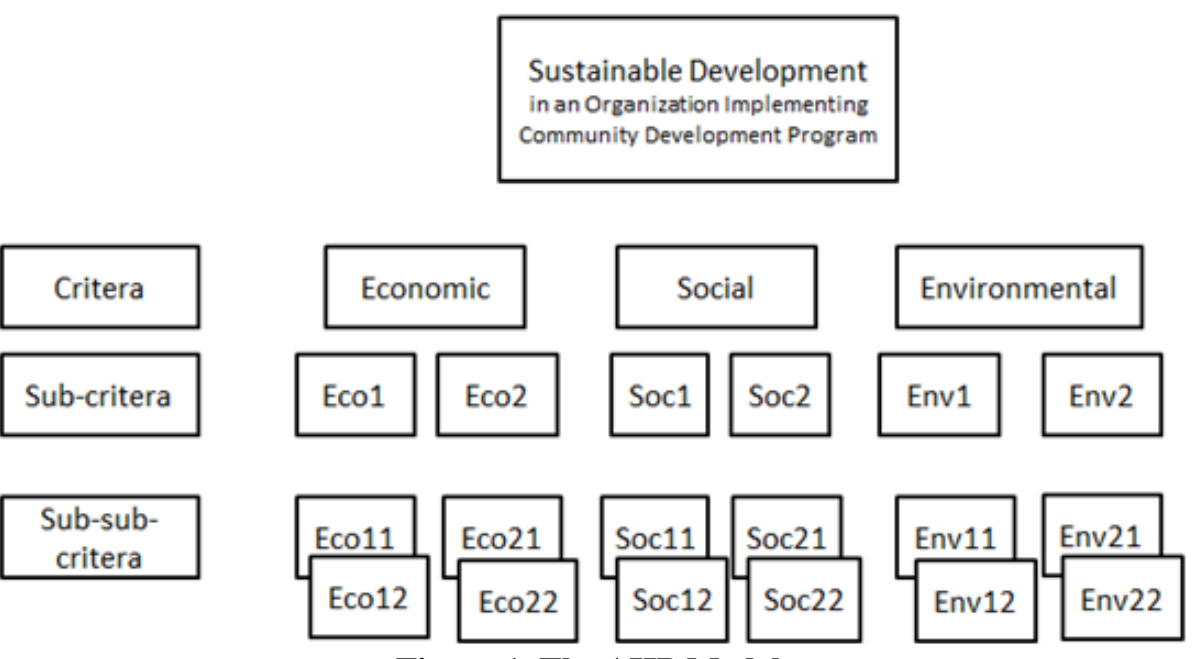

Figure 1. The AHP Model

Criteria or objectives can be divided into sub- or sub-sub-criteria (objectives) for additional information and for clarification and refinement. Criteria can be subjective (such as impact of trees on recreational values) or objective (such as tree planting cost), depending on the means used in evaluating the contribution of those criteria below them in the hierarchy. Criteria are regarded as mutually exclusive and do not depend on the elements below them in the hierarchy.

AHP has been applied in many and diverse areas of decision-making. With respect to environmental management, a selection of applications is indicated in Table 2. 
Table 2. Application of AHP in Relevant Studies

\begin{tabular}{ll}
\multicolumn{1}{c}{ Author/s and Country } & \multicolumn{1}{c}{ Application Area } \\
\hline [8], USA & Evaluation of strategies for the safe disposal of high-level nuclear waste \\
[9], USA & $\begin{array}{l}\text { Fisheries management in Maryland's river herring fishery } \\
\text { Integration of biodiversity into forest management planning and decision- } \\
\text { making }\end{array}$ \\
[10], Finland & Participative forest management planning of a nature conservation area \\
[11], Finland & Determining relative importance of risk factors for spruce beetle outbreaks \\
[13], Canada & Analyzing uncertainties in experts' opinions of forest plan performance \\
[12], Finland & Timber harvest scheduling problems with multiple criteria \\
[14], Spain & Optimal crop planning for a groundwater irrigation project \\
[15], Thailand & Multicriteria group decision-making for environmental conflict analysis \\
[17], Mexico & Ranking issues, projects and sites in integrated catchment management \\
[18], Australia & Pest plant prioritization process in weed management \\
[19], Australia &
\end{tabular}

[8] Used AHP in comparing options for management of high-level nuclear waste, a complex decision problem involving many factors of a technological, environmental, social and political nature. They argued that there are many alternatives being proposed for the disposal of waste but, because of the lack of data, it is not an easy task to find the best alternative. In large part, the decision depends on the judgments of experts.

[9] Noted that a major attraction of AHP is that it provides a framework for the decision-support process that is lacking in most fishery management agencies. They considered four groups of major factors or criteria for Maryland's river herring fishery, namely biological, political, economic and social. Three fishery management policy alternatives were compared with respect to each criterion. The authors concluded that AHP can provide a useful tool to assess policies regarding multi-species management and resource allocation among user groups.

[10] Used AHP to integrate biodiversity into forest management planning. They regarded biodiversity as comprising three species characteristics, namely richness, rarity and vulnerability. Importance weights of the components of biodiversity were assessed by pairwise comparisons, provided by an expert in conservation biology. In the planning problem of multiple-use forestry, maximizing biodiversity was added as an objective to a decision hierarchy. The weighting of biodiversity, in relation to other objectives, was based on the preferences of the forest managers.

In a related paper, [11] applied AHP for taking public preferences into account in choosing the management strategy for a forest area. [11] Argued that there is no limit on the levels in the planning hierarchy to which AHP can be applied in management planning. [11] Applied the approach at the national level for optimizing the number, size and spatial distribution of protected natural areas with respect to various dimensions of biological diversity. This allowed the local, regional and national economic and social consequences of such protection to be compared. In a subsequent study, [12] used AHP and a Bayesian extension of the regression technique to aid forest owners in the planning of future treatment schedules under uncertainty.

[13] Analyzed relative importance of risk factors for spruce beetle outbreaks in Alaska, organizing these risk factors into a hierarchical model. They argued that AHP is an effective method for eliciting expert knowledge and can be a useful tool for development of expert systems in natural resource management, where even expert knowledge is often incomplete.

[14] Derived preference weights from the application of AHP to a group of forestry experts. They incorporated these weights in a goal programming model, and tested several utility formulations including an additive and a Rawlsian function. This approach accommodated the multiplicity of criteria involved in the forest planning problem, and the solution generated by the model could be incorporated in utility terms without resort to complex multi-attribute utility formulations.

[15] [16] Used AHP to select the optimal cropping plan in a multi-objective analysis, taking into account the preferences of the decision-makers, including farmers and irrigation project managers. [17] developed a model to deal with a multicriteria group decision-making problem involving a set of feasible landuse options. The AHP was integrated with integer mathematical programming. They argued that the land suitability coefficients derived from AHP represent the contributions of particular attributes to the overall goal. When analyzed by means of integer programming, the land suitability coefficients may be used to determine the land-use pattern that maximizes consensus among interest groups.

[18] Applied AHP to three types of integrated catchment management problems (namely issues, projects and sites) in Victoria, Australia. They developed a software package called 'Catchment Decision Assistant' to link the AHP decision-making framework to geographic information systems. They used the package to: record the criteria and decision hierarchy; generate weights for each criteria; provide a framework 
for rating issues, projects and sites against the criteria; and report the results in tabular form (with mapping of sites). They reported the results of two pilot studies in the application of AHP to regional catchment issues including pest plants and biodiversity.

[18] Examined the utility of AHP as a tool for capturing knowledge on environmental systems where data are lacking. They argued that AHP has great potential for integrating judgments of experts with scientific information. They linked this technique to geographic information systems to overcome AHP limitations for ranking catchment issues that have a spatial dimension. This study demonstrated the use of AHP for capturing the knowledge of horticultural experts to rate factors for assessment of biophysical capability for horticultural crops, for the West Gippsland Catchment Management Authority in Victoria, Australia. The authors noted a caution in use of AHP; because the technique assumes linear relationships between variables, there are many cases where the pairwise comparison technique is not appropriate. However, the method of building a treestructured hierarchy for criteria is seen as a productive framework for capturing expert judgment.

[19] Developed an AHP-based risk assessment model that can be applied as a stand-alone procedure or integrated with a GIS-based system to determine resource conditions and then the risk or threat that weeds pose to these values. These authors argued that the AHP process allows for consultation with land managers to identify what land values are important to them and to place importance weights on these values. Weeds then can be assessed as threats against these values.

\section{Estimating Importance Weights Associated With}

\section{Sustainable Development}

To elicit the preferences and weights of the stakeholder groups with respect to the major goal, the objectives, the sub-objectives, and the sub-sub-objectives, a hierarchy was formed (see Figure 1) and then a questionnaire was developed using the hierarchy framework. The hierarchy consisted of four levels. Level 1 defines the central aim or major goal of the decision problem, i.e. sustainable development. At level 2, the major goal is decomposed into three major objectives for sustainable development, namely environmental, social and economic objectives. At level 3, each objective is divided into sub-objectives which are meaningful to various stakeholder groups. The objectives are partitioned logically in a top-down fashion into another level representing their sub-objectives.

Respondents were asked to choose between various pairs of statements. For example, to elicit preferences for environmental versus social objectives, the following set of statements was presented to each respondent:

For sustainable development, economic issues are:

$$
\text { equally as important as }
$$

moderately more important/moderately less important than than

strongly more important/strongly less important than than

very strongly more important/very strongly less important than than

extremely more important/extremely less important than than social issues

The five statements correspond to importance weights of 1,3, 5, 7 and 9 in the scale [20]. Prompt cards were used during interviews to explain the structure of the questionnaire and to present the questions. Workers are potentially the group most affected by BLPT; 13 person agreed to be interviewed. Interviews took about two to three hours.

A Microsoft Excel spreadsheet has been used to calculate average scores of the criterion and the subcriterion. Mean scores were calculated from the individual scores on the scale of 1 to 9 provided by the 13 workers. The Excel has been used to estimate weights of the importance of the three major criterion (environmental, economic and social) and their sub-criterion.

Priorities or weights for each criterion, sub-criterion and sub-sub-criterion are presented in Table 3. The first, second, and third column correspond to the information in Table 1.

Table 3. Priorities of Criterion

\begin{tabular}{|c|c|c|c|c|c|}
\hline Criteria & Sub-Criteria & Sub-Sub-Criteria & Weights & $\begin{array}{c}\text { Normalized } \\
\text { Weights } \\
\end{array}$ & Rank \\
\hline Economy (E) & Income (ECO1) & $\begin{array}{l}\text { Revenue for the management and admin BLPT } \\
\text { (ECO11) }\end{array}$ & 0.259 & 0.043 & 7 \\
\hline \multirow{4}{*}{0.669} & & Revenue for suppliers of coconut wood (ECO13) & 0.098 & 0.016 & 15 \\
\hline & & Revenue for permanent workers (ECO14) & 0.374 & 0.062 & 6 \\
\hline & & Revenue for temporary workers (ECO15) & 0.039 & 0.006 & 18 \\
\hline & creation & Job for loggers (one package with the supplier) & 0.220 & 0.037 & 9 \\
\hline
\end{tabular}




\begin{tabular}{|c|c|c|c|c|c|}
\hline & $(\mathrm{ECO} 2)$ & $(\mathrm{ECO} 21)$ & & & \\
\hline & 0.833 & Job for transporting coconut wood (ECO22) & 0.100 & 0.017 & 14 \\
\hline 0.243 & 0.875 & $\begin{array}{l}\text { Increasing expertise and skills for school dropouts } \\
\text { (SOC12) }\end{array}$ & 0.218 & 0.036 & 10 \\
\hline & $\begin{array}{l}\text { Social Relation } \\
\text { (SOC2) }\end{array}$ & $\begin{array}{l}\text { The relationship between the owner of a palm tree } \\
\text { with a team of contractors/suppliers (SOC } 21 \text { ) }\end{array}$ & 0.081 & 0.013 & 16 \\
\hline & 0.125 & $\begin{array}{l}\text { The relationship between land owners with coconut } \\
\text { tree growers (SOC22) }\end{array}$ & 0.731 & 0.122 & 3 \\
\hline & & $\begin{array}{l}\text { The relationship between coconut trees suppliers } \\
\text { with BLPT (SOC11) }\end{array}$ & 0.188 & 0.031 & 12 \\
\hline 0.088 & 0.833 & Planting coconut trees on vacant land (ENV12) & 0.750 & 0.125 & 2 \\
\hline & $\begin{array}{l}\text { Recycling waste } \\
\text { of coconut trees } \\
\text { (ENV2) }\end{array}$ & Utilization of waste for fuel (ENV21) & 0.125 & 0.021 & 13 \\
\hline & 0.167 & Utilization of waste for handicraft (ENV22) & 0.875 & 0.146 & 1 \\
\hline
\end{tabular}

It shows from Table 3 that "Utilization of waste for handicraft (ENV22)" has the first rank, "Planting coconut trees on vacant land (ENV12)" locates in the second rank, and "The relationship between land owners with coconut tree growers (SOC22)" in the third rank. Moreover, it also shows that "Improving education for children (SOC11)" has the fourth rank and "Job for processed coconut wood (furniture and souvenirs)" (ECO23)" in the fifth rank.

\section{Concluding Comments}

This study demonstrates that environmental, social and economic objectives could be identified and measured by applying AHP. It shows from Table 3 that "Utilization of waste for handicraft (ENV22)" has the first rank, "Planting coconut trees on vacant land (ENV12)" locates in the second rank, and "The relationship between land owners with coconut tree growers (SOC22)" in the third rank. Based on sustainable development framework and the rank shown in Table 3, it could be said that BLPT has more environmetal and social characters than economic one. This information is useful for organization leaders when evaluating the appropriateness of alternative policies in implementing sustainable development.

\section{References}

[1]. K. H. Robèrt, B. Schmidt-Bleek, A.L. Jacqueline,B. George, J. L. Jansen, R. Kuehr, P. P. Thomas, M. Suzuki, P. Hawken, and M. Wackernagel., Strategic sustainable Development-Selection, Design and Synergies of Applied Tools., 2002, Journal of Cleaner production 10, (3), 197-214.

[2]. P. Kristjanson,F. Place, S. Franzel and PK. Thornton., Assessing Research Impact On Poverty: the Importance of Farmers' Perspectives., 2002, Agricultural Systems, 72(1), 73-92.

[3]. Narumalani, S., Zhou, Y. and Jensen, J. R., 'Application of Remote Sensing And Geographic Information Systems To The Delineation and Analysis of Riparian Buffer Zones', 1997, Aquatic Botany, 58: 393-409.

[4]. Saaty, T. L., Decision Making for Leaders: the Analytic Hierarchy Process for Decisions in a Complex World, RWS Publications, Pittsburgh, 1995.

[5]. E.C.Inc. (Expert Choice Inc.), Decision Support Software: Tutorial, Expert Choice, Student Version 9, Expert Choice Inc., Pittsburgh, 1995.

[6]. Harrison, S.R. and Qureshi, M. E., Identification of Stakeholder Objectives for Multicriteria Analysis, Paper Presented at The 2nd International Conference on Multiple Objective Decision Support Systems, Sheraton Hotel, Brisbane, 1-6 August, 1999.

[7]. Saaty, T. L., The Analytic Hierarchy Process, 2nd edn, RWS Publications, Pittsburgh, 1990.

[8]. Saaty, T. L., and Gholamnezhad, H., 'High-Level Nuclear Waste Management: Analysis of Options', 1982, Environment and Planning B, 9(1): 181-196.

[9]. DiNardo, G., Levy, D. and Golden, B., 'Using Decision Analysis to Maryland's River Herring Fishery: An application of AHP', 1989, Journal of Environmental Management, 29(1): 193-213.

[10]. Kangas, J. and Kuusipalo, J., 'Integrating Biodiversity Into Forest Management Planning and Decision-Making', 1993, Forest Ecology and Management, 61(1): 1-15.

[11]. Kangas, J., 'An Approach To Public Participation In Strategic Forest Management Planning', 1994, Forest Ecology and Management, 70(1): 75-88

[12]. Alho, J. M. and Kangas, J. ‘Analysing Uncertainties In Experts' Opinions of Forest Plan Performance', 1997, Forest Science, 43(4): $521-528$. 
[13]. Reynolds, K.M., and Holsten, E.H., 'Relative Importance of Risk Factors for Spruce Beetle Outbreaks', 1994, Canadian Journal of Forest Research, 24(1): 2089-2095.

[14]. Diaz-Balteiro, L. and Romero, C., 'Modeling Timber Harvest Scheduling Problems With Multiple Criteria: an Application in Spain' 1997, Forest Science, 44(1): 47-57.

[15]. Mainuddin, M., Gupta, A. D. and Onta, P. R., 'Optimal Crop Planning Model for an Existing Groundwater Irrigation Project in Thailand' 1997, Agricultural Water Management, 33(1): 43-62.

[16]. Janssen, R. and van Herwijnen, M., DEFINITE: A System to Support Decisions on a Finite Set of Alternatives: User Manual. Environment and Management 3, Kluwer Academic Publishers, Dordrecht. 1994.

[17]. Malczewski, J., Moreno-Sanchez, R., Bojorquez-Tapia, L. A. and Ongay-Delhumeau, E., 'Multicriteria Group Decision-Making Model for Environmental Conflict in the Analysis in the Cape Region, Mexico', 1997, Journal of Environmental Planning and Management, 40(3): 349-374.

[18]. Itami, R. and Cotter, M., 'Application of Analytical Hierarchy Process to Rank Issues, Projects and Sites in Integrated Catchment Management', 1999, in P.A. Lawrence and J. Robinson (eds), Proceedings of the 2nd International Conference on Multiple Objective Decision Support Systems for Land, Water and Environmental Management (MODSS'99), Queensland Department of Natural Resources and Mines, Brisbane, Australia 2002, Report QNRM02143.

[19]. Weiss, J. and McLaren, D., 'Victoria's Pest Plant Prioritisation Process', in H. S. Jacobs, J. Dodd and J. H. Moore (eds), Proceedings of the Thirteenth Australian Weeds Conference, Plant Protection Society of Western Australia, 2002, Perth, pp. 509512 .

[20]. Saaty, T. L., Decision Making for Leaders: the Analytic Hierarchy Process for Decisions in a Complex World, RWS Publications, Pittsburgh. 1995. 